\title{
Sampling methane in basalt on Earth and Mars
}

\author{
Sean McMahon', John Parnell' and Nigel J.F. Blamey² \\ ${ }^{1}$ School of Geosciences, University of Aberdeen, Aberdeen AB24 3UE, UK \\ e-mail: sean.mcmahon@abdn.ac.uk \\ ${ }^{2}$ Department of Earth and Environmental Science, New Mexico Tech, Socorro, NM 87801, USA
}

\begin{abstract}
If confirmed, the extremely low concentrations of methane $\left(\mathrm{CH}_{4}\right)$ detected in the Martian atmosphere may represent reservoirs and emission processes that would normally be considered negligible on Earth. One such process is the release of ancient volatiles from fluid inclusions and interstitial sites in rocks and minerals during erosion or geothermal activity. Using a highly sensitive rock-crushing and mass-spectrometry technique previously shown to detect $\mathrm{CH}_{4}$ in serpentinites and hydrothermal mineral deposits, we have demonstrated that $\mathrm{CH}_{4}$ and other ancient volatiles can be recovered from basalt, the dominant rock type on the Martian surface. Basalt samples from a wide range of ages and geological systems were tested, all of which released $\mathrm{CH}_{4}$ when crushed. Oxidative weathering was associated with lower quantities of $\mathrm{CH}_{4}$. Otherwise, $\mathrm{CH}_{4}$ recoverability showed no relationship with age or geological context. Mineral veins, cross-cutting one locality were found to share the volatile composition of the basalt.

In general, the results suggest that $\mathrm{CH}_{4}$-release from ancient basalts could be a significant process on Mars, which could be further investigated by Martian rovers using a similar rock-crushing and mass spectrometry technique in situ.

Received 13 April 2012, accepted 1 November 2012, first published online 2 January 2013
\end{abstract}

Key words: basalt, biogenic, methane, Martian, serpentinite.

\section{Introduction}

Spatially and temporally variable methane $\left(\mathrm{CH}_{4}\right)$ concentrations on the order of tens of parts per billion by volume (ppbv) were detected in the Martian atmosphere by groundbased telescopes in 2003 (Mumma et al. 2009) and by the Mars Express orbiter in 2004 (Formisano et al. 2004). A 2010 reanalysis of earlier data from the Mars Global Surveyor orbiter also identified a seasonal $\mathrm{CH}_{4}$ signature with maxima of about 50 ppbv over the Elysium, Tharsis, and Arabia Terrae regions in the northern hemisphere (Fonti \& Marzo 2010). $\mathrm{CH}_{4-}$ concentrations apparently peak during northern-hemisphere summer and decline thereafter, with an inferred atmospheric lifetime of less than 200 Martian days (Lefèvre \& Forget 2009).

These surprising but mutually supportive results remain controversial (Zahnle et al. 2011) and await confirmation by NASA's Mars Science Laboratory and ESA's Trace Gas Orbiter (currently intended to reach Mars in 2016). If verified, the presence of $\mathrm{CH}_{4}$ indicates either or both: (1) extant biological or non-biological generation of $\mathrm{CH}_{4}$; (2) periodic release - perhaps due to seasonal pressure and temperature changes - from a vestigial reservoir of ancient biogenic or abiogenic gas.

Earth's atmospheric $\mathrm{CH}_{4}$ is predominantly biogenic, but methanogens are unlikely to be viable in the dry and oxidizing conditions at the $\mathrm{CH}_{4}$ surface. On the other hand, they could have thrived there in the geological past, and the subsurface may remain habitable today (Fisk \& Giovannoni 1999).
However, whereas Earth's atmospheric $\mathrm{CH}_{4}$ is replenished by a yearly supply of $6 \times 10^{14} \mathrm{~g}$ (Dentener et al. 2001), the low concentrations detected in Mars' tenuous atmosphere require an influx of only $2 \times 10^{8} \mathrm{~g}$ per year (Geminale et al. 2008). Hence, the production and emission mechanisms responsible for Martian atmospheric $\mathrm{CH}_{4}$ may be of such low yield that they would normally be considered insignificant on Earth.

Candidate sources for Martian $\mathrm{CH}_{4}$ include a range of geochemical processes known to reduce inorganic carbon in the terrestrial subsurface, of which serpentinization is the most significant (Oze \& Sharma 2005). Serpentinization is the aqueous alteration of the common igneous minerals olivine and pyroxene to the hydrous mineral serpentine via several exothermic reactions favourable below $300^{\circ} \mathrm{C}$. These reactions evolve $\mathrm{H}_{2}$, which reduces ambient $\mathrm{CO}_{2}$ to $\mathrm{CH}_{4}$. The $\mathrm{CO}_{2}$ on Earth includes magmatic carbon in basalts, but also $\mathrm{CO}_{2}$-rich groundwaters which interact with basalts so readily that the reactions have potential for sequestration of greenhouse gases (Schaef et al. 2009, 2010). The $\mathrm{CO}_{2}$ on Mars could ultimately be derived from mantle, atmospheric or meteoritic infall sources (Grady et al. 2004). Experiments have confirmed the production of $\mathrm{H}_{2}$ and $\mathrm{CH}_{4}$ from the aqueous alteration of olivine at temperatures as low as $30-70{ }^{\circ} \mathrm{C}$ (Neubeck et al. 2011). Olivine and pyroxene are major components of basalt, the glassy silicate rock that dominates the Martian crust. Liquid water has apparently been stable on the Martian surface for long periods of its history and may continue to circulate in the subsurface, driven by geothermal convection 
(Travis et al. 2003). Thus, serpentinization is likely to have generated $\mathrm{CH}_{4}$ in Mars' past and may continue to do so. Where carbon is available, e.g. from magmatic degassing, thermodynamic calculations predict that redox reactions with hydrothermal fluids could also generate $\mathrm{CH}_{4}$ from basalt or magma (Lyons et al. 2005). Other reduced organic carbon molecules have already been detected in a range of Martian meteorites (Steele et al. 2012).

Intracrystalline 'fluid inclusions' and crystal boundaries in basalt and other mafic and ultramafic igneous rocks are known to incorporate and retain $\mathrm{CH}_{4}$ and other volatiles (liquids and gases) formed by serpentinization as well as other geological processes (e.g. Welhan 1988; Kelley 1996). Clay minerals in altered basalts can also adsorb $\mathrm{CH}_{4}$ (e.g. Gough et al. 2010). Thus, Martian basalt could serve as both a record of ancient methanogenic processes and a reservoir from which ancient $\mathrm{CH}_{4}$ might escape. As a first step in evaluating the significance of this reservoir, we investigated the potential for sampling and detecting $\mathrm{CH}_{4}$ in basalts using an incremental-crushing mass spectrometry technique previously found to detect $\mathrm{CH}_{4}$ in serpentinites (Parnell et al. 2010), artificial impact craters (McMahon et al. 2012a) and hydrothermal minerals (McMahon et al. 2012b). This technique has potential for application in situ on the Martian surface.

\section{Objectives}

The key questions were the following:

(i) $\mathrm{Can} \mathrm{CH}_{4}$ always be detected by this technique in basalts from Earth?

If all or most terrestrial basalts yield $\mathrm{CH}_{4}$, we would expect the same on Mars, given evidence of comparable mineralogy (McSween et al. 2009). This expectation would be strengthened if $\mathrm{CH}_{4}$ contents were consistently high across a wide range of altered, unaltered, recently erupted and ancient basalts in different eruptive settings.

(ii) Does particle size affect the sampling or analysis of gas?

A limited range of particle sizes may be available for in situ analysis on Mars. A future rover, for example, will carry a Sample Preparation and Distribution System (SPDS) capable of crushing geological samples to a broad grain-size distribution up to $400 \mu \mathrm{m}$ (Schulte et al. 2008). It is therefore of particular interest to establish how $\mathrm{CH}_{4}$ recoverability varies with particle size within this range. Most inclusion volatiles are present in relatively large $(10 \mathrm{~s}$ of $\mu \mathrm{m})$ inclusions, which are opened and evacuated when grains are broken, whereas finer samples, having already lost these large volumes of volatiles, yield proportionally more crystal-boundary gas when crushed. $\mathrm{CH}_{4} / \mathrm{CO}_{2}$ ratios in hydrothermal calcite veins were previously observed to vary systematically with particle size, interpreted to suggest a difference in composition between inclusion volatiles and crystal-boundary volatiles (McMahon et al. 2012b).

(iii) Can we relate detected variations in $\mathrm{CH}_{4}$ quantity to the geological context of basalts, e.g. eruption depth and vesicularity?

An affirmative result could constrain the quantity of $\mathrm{CH}_{4}$ likely to be retained in Martian basalt and inform sampling strategies for lander missions. (iv) Does $\mathrm{CH}_{4}$ content vary systematically with basalt age?

It is important to establish the stability and consistency of volatile retention in basalts over geological time. Any trends in $\mathrm{CH}_{4}$ recoverability might reflect: (a) secular changes in Earth's carbon cycle; (b) diffusion, weathering or diagenesis; (c) chance.

(v) Does oxidative weathering preclude or obscure measurements of ancient $\mathrm{CH}_{4}$ ?

Oxidative weathering pervades the Martian near-surface and may affect the composition of interstitial volatiles. Crystalboundary $\mathrm{CH}_{4}$ in basalt may be gradually oxidized or analytically masked by $\mathrm{CO}_{2}$. Oxidized basalts can be easily identified from their penetrative red discoloration.

(vi) Do mineral veins cross-cutting basalts share the same gas composition?

An affirmative result might suggest that hydrothermal systems can remobilize $\mathrm{CH}_{4}$ from basalt, a possible venting mechanism. Hydrothermal systems are likely to occur on Mars as a result of geothermal heat (Travis et al. 2003) and may be locally increased by impact cratering and magmatic activity. Previous results demonstrate that terrestrial hydrothermal calcite veins entrain $\mathrm{CH}_{4}$ in quantities varying according to the thermal maturity of organic-rich sediments through which they were injected (McMahon et al. 2012b).

\section{Method}

\section{Sampling programme}

An incremental-crushing mass-spectrometry technique was applied to a wide range of basalt samples (Table 1). To answer questions (i) and (iii) above, ancient oceanic vesicular, amygdaloidal and non-vesicular basalts were sampled from ten localities in the British Isles, one in Michigan, USA, one in Gävle, Sweden and one in Ontario, Canada; and recent subaerial basalts were collected from near Lake Myvatn in Iceland and Kilauea in Hawaii. An olivine bomb (xenolith) derived from the upper mantle was also collected from recent basalt in Tenerife. To address question (iv), Archean, Mesoproterozoic, Neoproterozoic, Carboniferous, Ordovician, Palaeocene and Recent basalts were sampled. At five localities basalts experienced contemporaneous oxidation (permeated by red discoloration due to weathering of lava flows) and were sampled to investigate question (iv). Ordovician basalt from Helen's Bay in County Down, Northern Ireland was sampled along with two generations of cross-cutting mineral veins, addressing question (v). The older vein, calcite, was sampled directly. The younger, haematite, was formed during Permo-Triassic uplift and weathering. Samples were removed from its (visibly oxidized) alteration halo.

Basalt samples from Helen's Bay were crushed in a press and sieved through four mesh sizes - 63, 125, 212 and $425 \mu \mathrm{m}-$ in order to investigate question (ii). All other samples were crushed in a press to obtain grains about $3 \mathrm{~mm}$ in diameter. Care was taken to avoid unintentionally sampling veins, amygdales, or visible alteration halos. All samples were then 
Table 1. Details of the basalt samples analysed for $\mathrm{CH}_{4}$

\begin{tabular}{llll}
\hline Sample type & Locality & Age & Reference \\
\hline Amygdaloidal pillow basalt & Schreiber, Ontario, Canada & Archean & Polat et al. (1998) \\
Pillow basalt & Hamrånge, Gävle, Sweden & Palaeoproterozoic & Ogenhall (2007) \\
Oxidized amygdaloidal basalt & Keweenaw Peninsula, Michigan, USA & Mesoproterozoic & Bornhorst \& Rose (1994) \\
Amygdaloidal pillow basalt & Kiell's Jetty, Argyll, Scotland & Neoproterozoic & Gower (1977) \\
Pillow basalt & Penryn Nefyn, Gwynedd, Wales & Neoproterozoic & Kawai et al. (2007) \\
Oxidized pillow basalt & Ballantrae, South Ayrshire, Scotland & Ordovician & Bluck (1992) \\
Pillow basalt & Helen's Bay, Co. Down, Northern Ireland & Ordovician & Craig (1983) \\
Calcite veins & & & \\
Haematite vein oxidation halo & & & Ordovician \\
Pillow basalt & Stonehaven, Aberdeenshire, Scotland & Carboniferous & Thomas (1999) \\
Amygdaloidal basalt & Kinghorn, Fife, Scotland & Palaeoecene & Lyle \& Preston (1993) \\
Oxidized subaerial basalt & Giant's Causeway, Co. Antrim, Northern Ireland & Palaeocene & Anderson \& Dunham (1966) \\
Pillow basalt & Glen Drynoch, Skye, Scotland & Palaeocene & Eyles (1952) \\
Oxidized pillow basalt & Newtown Crommelin, Co. Antrim, Northern Ireland & Lyle \& Preston (1993) \\
Subaerial basalt & Portballintrae, Co. Antrim, Northern Ireland & Palaeocene & Anderson \& Dunham (1966) \\
Oxidized pillow basalt & Portree, Skye, Scotland & Palaeocene & N/A \\
Fresh subaerial basalt & Kilauea, Hawaii, USA & Recent & N/A \\
Fresh subaerial basalt & Lake Myvatn, Iceland & Recent & N/A \\
Olivine xenolith in basalt & Tenerife, Spain & Recent & \\
\hline
\end{tabular}

Table 2. Relative abundance of species recovered from a basalt sample (Penryn Nefyn, Gwynedd, Wales; Ordovician) using the CFS technique. Water is set to 0; percentages represent the remainder. $\mathrm{SO}_{2}$ and organics other than $\mathrm{CH}_{4}$ are usually excluded from analysis. This sample would be reported to have a $\mathrm{CH}_{4} / \mathrm{CO}_{2}$ ratio of $2.67 / 1.24=2.15$

\begin{tabular}{|c|c|c|c|c|c|}
\hline \multirow[b]{2}{*}{ Species } & \multicolumn{4}{|c|}{ Relative abundance, $\%$} & \multirow{2}{*}{$\begin{array}{l}\text { Mean weighted } \\
\text { by burst size }\end{array}$} \\
\hline & Crush 1 & Crush 2 & Crush 3 & Crush 4 & \\
\hline $\mathrm{H}_{2}$ & 6.61 & 6.72 & 6.81 & 13.63 & 8.82 \\
\hline $\mathrm{He}$ & 0.03 & 0.02 & 0.01 & 0.04 & 0.02 \\
\hline $\mathrm{CH}_{4}$ & 2.92 & 2.42 & 2.45 & 2.94 & 2.67 \\
\hline $\mathrm{N}_{2}$ & 86.41 & 88.54 & 88.63 & 81.33 & 86.04 \\
\hline $\mathrm{O}_{2}$ & 0.03 & 0.02 & 0.02 & 0.02 & 0.02 \\
\hline $\mathrm{Ar}$ & 0.26 & 0.16 & 0.19 & 0.23 & 0.21 \\
\hline $\mathrm{CO}_{2}$ & 2.38 & 1.08 & 1.11 & 0.87 & 1.24 \\
\hline $\mathrm{C}_{2} \mathrm{H}_{4}$ & 0.07 & 0.00 & 0.00 & 0.03 & 0.02 \\
\hline $\mathrm{C}_{2} \mathrm{H}_{6}$ & 0.00 & 0.00 & 0.00 & 0.00 & 0.00 \\
\hline $\mathrm{SO}_{2}$ & 0.63 & 0.33 & 0.29 & 0.36 & 0.38 \\
\hline $\mathrm{C}_{3} \mathrm{H}_{6}$ & 0.14 & 0.09 & 0.06 & 0.07 & 0.08 \\
\hline $\mathrm{C}_{3} \mathrm{H}_{8}$ & 0.43 & 0.48 & 0.37 & 0.43 & 0.42 \\
\hline $\mathrm{C}_{4} \mathrm{H}_{8}$ & 0.09 & 0.03 & 0.01 & 0.02 & 0.03 \\
\hline $\mathrm{C}_{4} \mathrm{H}_{10}$ & 0.00 & 0.01 & 0.03 & 0.02 & 0.02 \\
\hline Benzene & 0.00 & 0.09 & 0.02 & 0.02 & 0.03 \\
\hline Burst (amps) & $1.02 \mathrm{E}-08$ & $1.23 \mathrm{E}-08$ & $2.04 \mathrm{E}-08$ & $1.86 \mathrm{E}-08$ & \\
\hline
\end{tabular}

washed for about 5 minutes in $\mathrm{H}_{2} \mathrm{O}_{2}$ to remove surface organics, rinsed and dried at room temperature.

\section{CFS mass spectrometry}

Extraction and analysis of volatiles were performed by the crush-fast scan (CFS) method (Norman \& Moore 1997; Moore et al. 2001; Parry \& Blamey 2010; Blamey 2012), which offers very low detection limits (Blamey et al. 2012). Samples were loaded into a crushing chamber under an ultra-high vacuum (approximately $10^{-8}$ Torr) and crushed in swift increments, with each crush producing a burst of mixed volatiles. A typical sample size of about $250 \mathrm{mg}$ (one or two $3 \mathrm{~mm}$ grains) released four to ten bursts of volatiles (up to $\sim 2 \times 10^{-11}$ litres) into the vacuum chamber, which remained there for $8-10$ analyser scans ( $\sim 2$ seconds) before removal by the vacuum pump. This method does not require a carrier gas and volatiles are not separated from each other but released simultaneously into the chamber.

Bursts were analysed for $\mathrm{H}_{2}, \mathrm{He}, \mathrm{CH}_{4}, \mathrm{H}_{2} \mathrm{O}, \mathrm{N}_{2}, \mathrm{H}_{2} \mathrm{~S}$ (or $\mathrm{O}_{2}$ ), $\mathrm{Ar}, \mathrm{CO}_{2}, \mathrm{C}_{2} \mathrm{H}_{4}, \mathrm{C}_{2} \mathrm{H}_{6}, \mathrm{SO}_{2}, \mathrm{C}_{3} \mathrm{H}_{6}, \mathrm{C}_{3} \mathrm{H}_{8}, \mathrm{C}_{4} \mathrm{H}_{8}, \mathrm{C}_{4} \mathrm{H}_{10}$ and benzene using a Pfeiffer Prisma 'residual-gas' quadrupole mass spectrometers operating in fast-scan, peak-hopping mode at room temperature. In multiple ion-detection modes, both isotopic peaks and fragmentation peaks are observed; the major peaks for individual gases are generally selected but some exceptions occur. $\mathrm{O}_{2}$ and $\mathrm{H}_{2} \mathrm{~S}$ cannot be analysed together because $\mathrm{O}_{2}$ isotopologues at mass 34 obscure the typically much weaker $\mathrm{H}_{2} \mathrm{~S}$ signal at the same mass. In this 


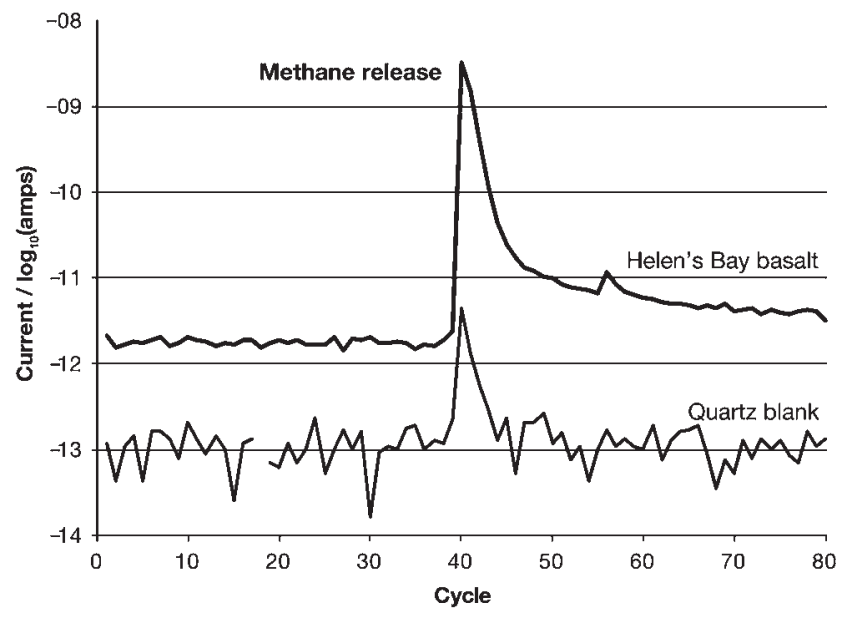

Fig. 1. Output from CFS-MS technique during $\mathrm{CH}_{4}$ release. Output from CFS-MS over 80 cycles (approx. 27 seconds) at $m / z=15$, representing ionized $\mathrm{CH}_{4}$ released during sample-crushing.

The ionized volatiles produce a current in the detector proportional to their amount. The signal from a basalt sample (Helen's Bay, Co.

Down, Northern Ireland; $\mathrm{CH}_{4} / \mathrm{CO}_{2} \approx 4$ ) is shown alongside a quartz blank with maxima aligned. The basalt's peak signal is about three orders of magnitude higher than the highest signal from the quartz blank.

study, most samples were analysed for $\mathrm{O}_{2}$ (at mass 32) rather than $\mathrm{H}_{2} \mathrm{~S}$. The samples generally produced much lower yields than routine aqueous fluid inclusions from geothermal systems or hydrothermal ore deposits for which the system was built. In order to enhance the detection of low-yield samples, a limited gas suite was selected for most samples, comprising $\mathrm{H}_{2}, \mathrm{He}$, $\mathrm{CH}_{4}, \mathrm{H}_{2} \mathrm{O}, \mathrm{N}_{2}, \mathrm{O}_{2}$, Ar and $\mathrm{CO}_{2}$, thus removing higher organics and $\mathrm{SO}_{2}$. In preliminary work, samples were analysed for $\mathrm{SO}_{2}$, $\mathrm{C}_{2} \mathrm{H}_{4}, \mathrm{C}_{2} \mathrm{H}_{6}, \mathrm{C}_{3} \mathrm{H}_{6}, \mathrm{C}_{3} \mathrm{H}_{8}, \mathrm{C}_{4} \mathrm{H}_{8}, \mathrm{C}_{4} \mathrm{H}_{10}$ and benzene, which were (each) found to constitute less than $1 \%$ of non-water volatiles on average; Ar typically constituted $0.1-1 \%$ and $\mathrm{He}$ typically constituted less than $0.1 \%$.

$\mathrm{CH}_{4}$ is detected at mass 15 (i.e. the $\mathrm{CH}_{3}^{+}$fragment; Fig. 1) to avoid interference by $\mathrm{O}^{-}$fragments from water (the $\mathrm{CH}_{4}$ peak at mass 15 is about $90 \%$ as intense as the peak at mass 16 ). $\mathrm{CH}_{3}^{+}$ fragments generated by other organic compounds are typically much less abundant and can be corrected for.

Calibration was checked against commercial standard gas mixtures, atmospheric capillary tubes and three fluidinclusion standards as described by Norman \& Blamey (2001). Instrumental blanks are also analysed routinely.

The amount of each species was calculated by proprietary software to provide a quantitative analysis, which is corrected for the instrumental background. Crushing does not liberate all the entrapped gas from samples, so data are generated as molar percentages rather than moles. To circumvent the dependence of individual percentages on irrelevant species, we report $\mathrm{CH}_{4}$ abundances as the ratio $\left(\mathrm{mol}_{0} \% \mathrm{CH}_{4}\right) /\left(\mathrm{mol}_{0} \mathrm{CO}_{2}\right)$, hydrogen abundances as $\left(\mathrm{mol}^{2} \% \mathrm{H}_{2}\right) /\left(\mathrm{mol}^{\circ} \mathrm{N} \mathrm{N}_{2}\right)$ and oxygen abundances as $\left(\mathrm{mol} \% \mathrm{O}_{2}\right) /\left(\mathrm{mol}^{2} \mathrm{~N}_{2}\right)$ (hereafter $\mathrm{CH}_{4} / \mathrm{CO}_{2}, \mathrm{H}_{2} / \mathrm{N}_{2}$ and $\mathrm{O}_{2} / \mathrm{N}_{2}$, respectively). As predicted by thermodynamic calculations of redox equilibria, $\mathrm{CO}_{2}$ is usually a dominant volatile

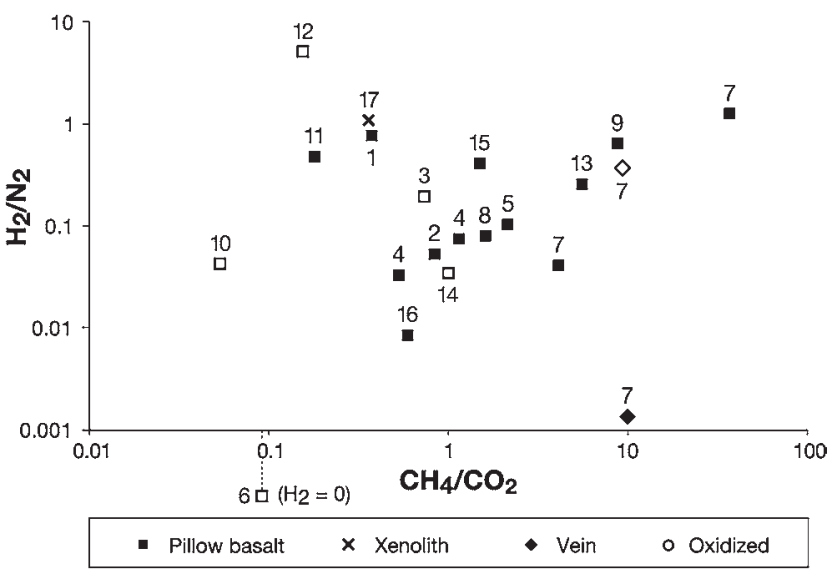

Fig. 2. Composition of volatile gases $\left(\mathrm{CH}_{4} / \mathrm{CO}_{2}\right.$ against $\mathrm{H}_{2} / \mathrm{N}_{2}$ molar ratios) in basalt and related samples. Each point represents the mean molar ratios obtained from several volatiles bursts and weighted by burst size. Both ratios increase with $\mathrm{H}_{2}$ fugacity, hence their apparent association. Archean: (1) Schreiber, Ontario, Canada.

Palaeoproterozoic: (2) Hamrånge, Gävle, Sweden. Mesoproterozoic: (3) Keweenaw Peninsula, Michigan, USA. Neoproterozoic: (4) Kiell's Jetty, Argyll, Scotland. (5) Penryn Nefyn, Gwynedd, Wales. Ordovician: (6) Ballantrae, South Ayrshire, Scotland. (7) Helen's Bay, Co. Down, Northern Ireland. (8) Stonehaven, Aberdeenshire, Scotland. Carboniferous: (9) Kinghorn, Fife, Scotland. Palaeocene: (10) Giant's Causeway, Co. Antrim, Northern Ireland. (11) Glen Drynoch, Skye, Scotland. (12) Newtown Crommelin, Co. Antrim, Northern Ireland. (13) Portballintrae, Co. Antrim, Northern Ireland. (14) Portree, Skye, Scotland. Recent: (15) Kilauea, Hawaii, USA. (16) Lake Myvatn, Iceland. (17) Tenerife, Spain. See Table 1 for more details.

in magmatic sources, second only to $\mathrm{H}_{2} \mathrm{O}$ (Lowenstern 2001). High values of $\mathrm{CH}_{4} / \mathrm{CO}_{2}$ are therefore a good indicator of elevated $\mathrm{CH}_{4}$ abundance in basalt.

\section{Results}

A typical set of results for a basalt sample is displayed in Table $2 . \mathrm{H}_{2} \mathrm{O}$ typically exceeded $90 \%$ of all volatiles released. Of the remaining $<10 \%, \mathrm{CH}_{4}, \mathrm{CO}_{2}, \mathrm{~N}_{2}$ and $\mathrm{H}_{2}$ were the most abundant constituents, each commonly accounting for between $0.1 \%$ and several $\%$ of total volatiles. Typical results for a basalt sample are shown in table 2. $\mathrm{CH}_{4}$ and $\mathrm{CO}_{2}$ were detected in all samples (Fig. 2), with $\mathrm{CH}_{4} / \mathrm{CO}_{2}$ ratios (means of several bursts, weighted by volatile burst size) ranging from 0.05 in oxidized Palaeocene basalt from Giant's Causeway (Co. Antrim, Northern Ireland) to 37.41 in non-oxidized Ordovician basalt from Helen's Bay (Co. Down, Northern Ireland). The mean $\mathrm{mol} \%$ (of the remainder after subtracting $\left.\mathrm{H}_{2} \mathrm{O}\right) \mathrm{CH}_{4}$ was about $20 . \mathrm{H}_{2} / \mathrm{N}_{2}$ was weakly correlated with $\mathrm{CH}_{4} / \mathrm{CO}_{2}$. Both ratios increase with $\mathrm{H}_{2}$ fugacity, hence their apparent association.

Four grain-size fractions of basalt from Helen's Bay were analysed: $<63,63-125,125-212$ and 212-425 $\mu \mathrm{m}$ (Fig. 3). The $212-425 \mu \mathrm{m}$ grains yielded the highest weighted mean $\mathrm{CH}_{4} / \mathrm{CO}_{2}$ ratio (44.7) followed by the $63-125 \mu \mathrm{m}$ (37.1), the 


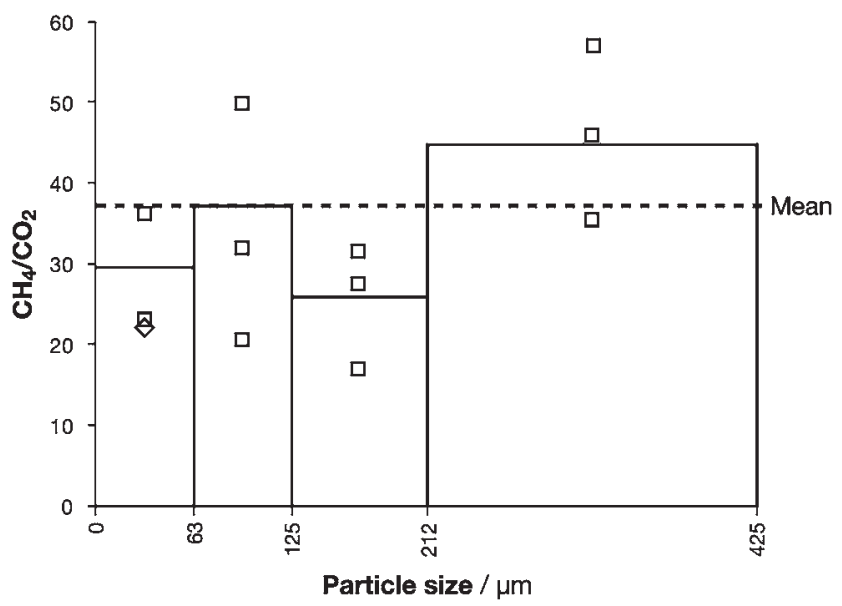

Fig. 3. Molar $\mathrm{CH}_{4} / \mathrm{CO}_{2}$ ratios in four particle-size fractions. The weighted mean ratio for each size fraction is presented as a bar; the individual bursts are presented as squares (or diamonds where points overlap). The dashed line represents the mean of all $\mathrm{CH}_{4} / \mathrm{CO}_{2}$ measurements of particles between 0 and $425 \mu \mathrm{m}$, weighted by burst size.

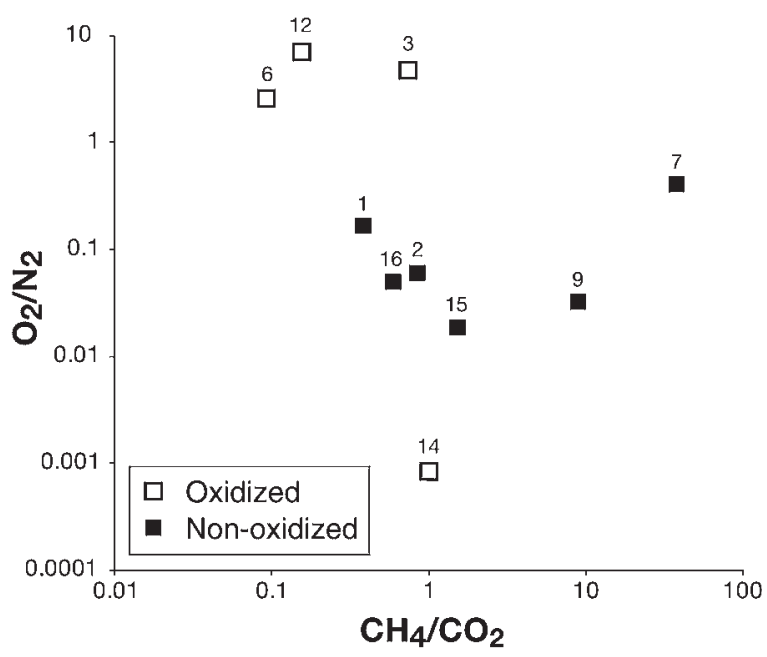

Fig. 4. $\mathrm{O}_{2} / \mathrm{N}_{2}$ plotted against $\mathrm{CH}_{4} / \mathrm{CO}_{2}$ molar ratios in oxidized and non-oxidized basalt. Archean: (1) Schreiber, Ontario, Canada. Palaeoproterozoic: (2) Hamrånge, Gävle, Sweden. Mesoproterozoic: (3) Keweenaw Peninsula, Michigan, USA. Ordovician: (6) Ballantrae, South Ayrshire, Scotland. (7) Helen's Bay, Co. Down, Northern Ireland. Carboniferous: (9) Kinghorn, Fife, Scotland. Palaeocene: (12) Newtown Crommelin, Co. Antrim, Northern Ireland. (14) Portree, Skye, Scotland. Recent: (15) Kilauea, Hawaii, USA. (16) Lake Myvatn, Iceland. Sample numbers are the same as in Figure 2. See Table 1 for more details.

$<63 \mu \mathrm{m}$ (29.6) and the 125-212 (26.1); hence, no clear trend was observed.

Of the ten basalt samples in which $\mathrm{O}_{2} / \mathrm{N}_{2}$ was measured, the three samples with the highest $\mathrm{O}_{2} / \mathrm{N}_{2}$ ratios were all oxidized, red basalt with low $\mathrm{CH}_{4} / \mathrm{CO}_{2}$ ratios. However, one other red basalt (Portree) yielded a very low $\mathrm{O}_{2} / \mathrm{N}_{2}$ ratio (Fig. 4). In general, pervasive reddening of basalt samples is broadly associated with lower $\mathrm{CH}_{4} / \mathrm{CO}_{2}$ ratios (Fig. 2). However, the reddened halo of a haematite vein in Helen's Bay basalt, in which vein volatiles had evidently infiltrated and oxidized the basalt, was found to have a similar volatile composition to the rest of the basalt. A calcite vein cross-cutting the Helen's Bay basalt also released gas of a similar composition to the rest of the basalt.

\section{Discussion}

The results allow assessment against the original objectives of the study.

(i) Can $\mathrm{CH}_{4}$ always be detected by this technique in basalts from Earth?

$\mathrm{CH}_{4}$ and $\mathrm{CO}_{2}$ were detected in all samples (Fig. 2). Most $\mathrm{CH}_{4} / \mathrm{CO}_{2}$ ratios were $>0.5$. The release of the gases during crushing implies that they were sealed within the sample before crushing, e.g. in fluid inclusions and on the tight crystal boundaries. The identification of $\mathrm{CH}_{4}$-bearing fluid inclusions in olivine crystals in other studies (Sachan et al. 2007; Arai et al. 2012) shows that significant quantities of $\mathrm{CH}_{4}$ can become trapped in olivine. $\mathrm{CH}_{4}$ can also be adsorbed on clay minerals produced by the alteration of basalt (e.g. Gough et al. 2010), which could also have contributed to the $\mathrm{CH}_{4}$ released during crushing.

(ii) Does particle size affect the sampling or analysis of gas?

Variation in gas composition with grain size was small $\left(\mathrm{CH}_{4} / \mathrm{CO}_{2}\right.$ fell within one order of magnitude) and no clear trend was observed in the basalt from Helen's Bay, Northern Ireland (Fig. 3). Given the reasonable assumption that finer particles yield proportionally more crystal-boundary (as opposed to fluid inclusion) gas when crushed, this result could suggest either that grain-boundary and inclusion volatiles shared a similar gas composition in this basalt or that one reservoir dominated the gas composition.

In previous work on hydrothermal calcite veins, grains below $<63 \mu \mathrm{m}$ yielded insufficient gas for analysis, having already liberated their volatiles during crushing and milling. It was suggested that this result provided an approximate lower limit to the particle size required for CFS. The new results are not consistent with that tentative conclusion, at least in the case of the basalt analysed. In any case, about $75-85 \%$ of the powder generated from basalt by the jaw crusher intended for the ExoMars rover (for example) falls within the range $63-400 \mu \mathrm{m}$ (Schulte et al. 2008), so success in analysing the $<63 \mu \mathrm{m}$ fraction is not critical.

(iii) Can we relate detected variations in $\mathrm{CH}_{4}$ quantity to the geological context of basalts?

No consistent differences were found between vesicular and non-vesicular or subaqueous and subaerial basalts, or between the olivine bomb and the rest of the basalts. This suggests that $\mathrm{CH}_{4}$ is incorporated into basalt in a wide range of geological contexts, perhaps reflecting basalt's inherent mineralogical susceptibility to serpentinization or hydrothermal alteration, and does not depend strongly on local microbial methanogenesis; however, we did not assess the biogenicity of the gas 
directly. The alteration process probably involves connate water, so the distinction of subaqueous and subaerial basalts may be of negligible importance.

(iv) Does $\mathrm{CH}_{4}$ content vary systematically with basalt age?

Some samples close in age appear to share similar $\mathrm{CH}_{4} / \mathrm{CO}_{2}$ ratios (e.g. Recent), but the data do not demonstrate long-term changes in the quantity of $\mathrm{CH}_{4}$ included or retained by basalt. It is unknown, however, whether $\mathrm{CH}_{4}$ recovered from ancient basalt is itself ancient. Overall, similar volatile compositions were observed for basalts of all ages.

(v) Does oxidative weathering preclude or obscure measurements of ancient $\mathrm{CH}_{4}$ ?

A previous CFS mass spectrometry study found no evidence that oxidative weathering affected gas compositions in hydrothermal calcite veins (McMahon et al. 2012b). In this study, however, pervasive reddening of basalt samples is broadly associated with lower $\mathrm{CH}_{4} / \mathrm{CO}_{2}$ ratios (Fig. 2). This suggests that oxidative weathering may change the volatile composition of basalts, for instance by oxidizing adsorbed and interstitial $\mathrm{CH}_{4}$ to $\mathrm{CO}_{2}$. Three out of four reddened basalts analysed for $\mathrm{O}_{2} / \mathrm{N}_{2}$ yielded high $\mathrm{O}_{2} / \mathrm{N}_{2}$ ratios and low $\mathrm{CH}_{4} / \mathrm{CO}_{2}$ ratios (Fig. 4). However, one reddened basalt yielded a very low $\mathrm{O}_{2} / \mathrm{N}_{2}$ ratio and a $\mathrm{CH}_{4} / \mathrm{CO}_{2}$ close to 1 . Moreover, all oxidized samples released some $\mathrm{CH}_{4}$ and the oxidation halo of the haematite vein in basalt from Helen's Bay showed no significant difference in $\mathrm{CH}_{4} / \mathrm{CO}_{2}$ ratio from non-oxidized basalt groundmass. Thus, the strength of the effect of oxidative weathering on gas composition is variable.

(vi) Do mineral veins cross-cutting basalts share the same gas composition?

Figure 5 shows the volatiles detected in two basalt samples and two veins, all from the Helen's Bay locality. Differences between the basalts may reflect differences in hydrothermal alteration, while the calcite vein shows a distinct volatile composition, most clearly by its lack of $\mathrm{H}_{2}$. The veins yielded similar $\mathrm{CH}_{4}, \mathrm{CO}_{2}$ and $\mathrm{CH}_{4} / \mathrm{CO}_{2}$ ratios to the host rock (Fig. 2 and Fig. 5), which is consistent with the possibility that they may have remobilized basaltic $\mathrm{CH}_{4}$, one of several plausible mechanisms for $\mathrm{CH}_{4}$ release to the surface. This is a small-scale equivalent of the release of $\mathrm{CH}_{4}$ through hydrothermal fracture systems on the sea floor (Charlou et al. 2002). Conversely, volatiles in hydrothermal fracture systems may also have influenced the gas composition of the basalt. This influence is less likely to have been significant at the other, less heavily veined localities.

\section{Comparison with other datasets}

Comparison of the basalt dataset with measurements from modern environments (sea floor hydrothermal fluids, Icelandic groundwaters and a hydrocarbon-bearing system; Charlou et al. 2002; Stefánsson \& Arnórsson 2002; Parry \& Blamey 2010) shows that higher $\mathrm{CH}_{4} / \mathrm{CO}_{2}$ ratios are recorded from the basalts (Fig. 6a). This is consistent with a progressive build-up of $\mathrm{CH}_{4}$ in the basalts over time. Basalt data can also be compared with other geological materials previously analysed by the CFS technique (Fig. 6b; Parnell et al. 2010; McMahon et al. 2012b). This comparison reveals that most basalts in this

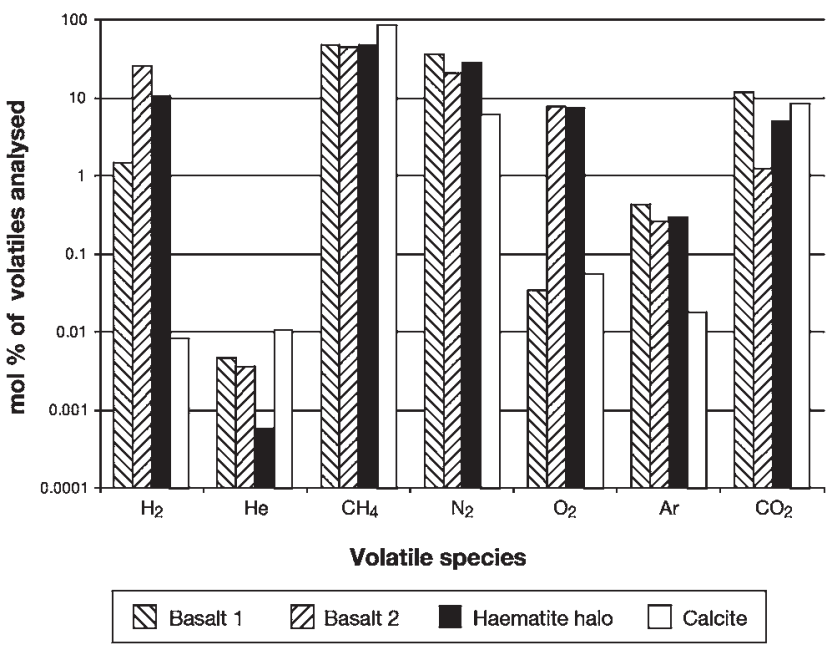

Fig. 5. Comparison of gas compositions in two basalt samples, a calcite vein, and the oxidation halo of a magnetite vein, all from Helen's Bay, Co. Down, Northern Ireland. Percentage abundances refer only to the seven volatiles presented; water is excluded and no other volatiles were analysed. The hatched bars represent two basalt samples, the black bars represent the alteration halo of a haematite vein through basalt, and the white bars represent a calcite vein in basalt. Differences between the basalts may reflect differences in hydrothermal alteration, while the calcite vein shows a distinct volatile composition, most clearly by its lack of $\mathrm{H}_{2}$. However, $\mathrm{CH}_{4}$ and $\mathrm{CO}_{2}$ are similar for all four samples, which is consistent with gas exchange between the basalt and the veins.

study yielded lower $\mathrm{CH}_{4} / \mathrm{CO}_{2}$ ratios than previously studied serpentinites, which might be expected if the $\mathrm{CH}_{4}$-enrichment of the basalts is mostly due to serpentinization. Nevertheless, some basalt yielded $\mathrm{CH}_{4} / \mathrm{CO}_{2}$ ratios as high as some serpentinites, despite the high concentration of $\mathrm{CO}_{2}$ in magmatic systems.

\section{Sources of $\mathrm{CH}_{4}$ in terrestrial and Martian basalt}

Although the present study did not seek to determine the ultimate sources of the $\mathrm{CH}_{4}$ detected in terrestrial basalt, it would be an interesting question to explore further. Methanogens are known to thrive in hydrothermal systems associated with midocean ridges, but are unlikely to have contributed significantly to the basalts formed in other settings. It is also possible that some $\mathrm{CH}_{4}$ arrived in the basalt via the thermal breakdown of biogenic organic matter (kerogen) in sediments, sedimentary rock, and circulating fluid. Such 'thermogenic' gas commonly includes higher alkanes; we did not test for these in all samples, but found only trace amounts during preliminary work on samples from five localities. Ultimately, the biosphere is inextricable from the Earth's carbon cycle and subducted biological material may re-emerge in magmatic gases; Sleep et al. (2012) have recently shown that $\mathrm{N}_{2}$ in mid-ocean ridge basalt derives from this source.

A magmatic $\mathrm{CH}_{4}$ source is thermodynamically unlikely. Redox equilibration between basaltic magma and hydrothermal $\mathrm{C}-\mathrm{O}-\mathrm{H}$ fluids is constrained by the QFM (quartzfayalite-magnetite) mineral redox buffer, which predicts very 

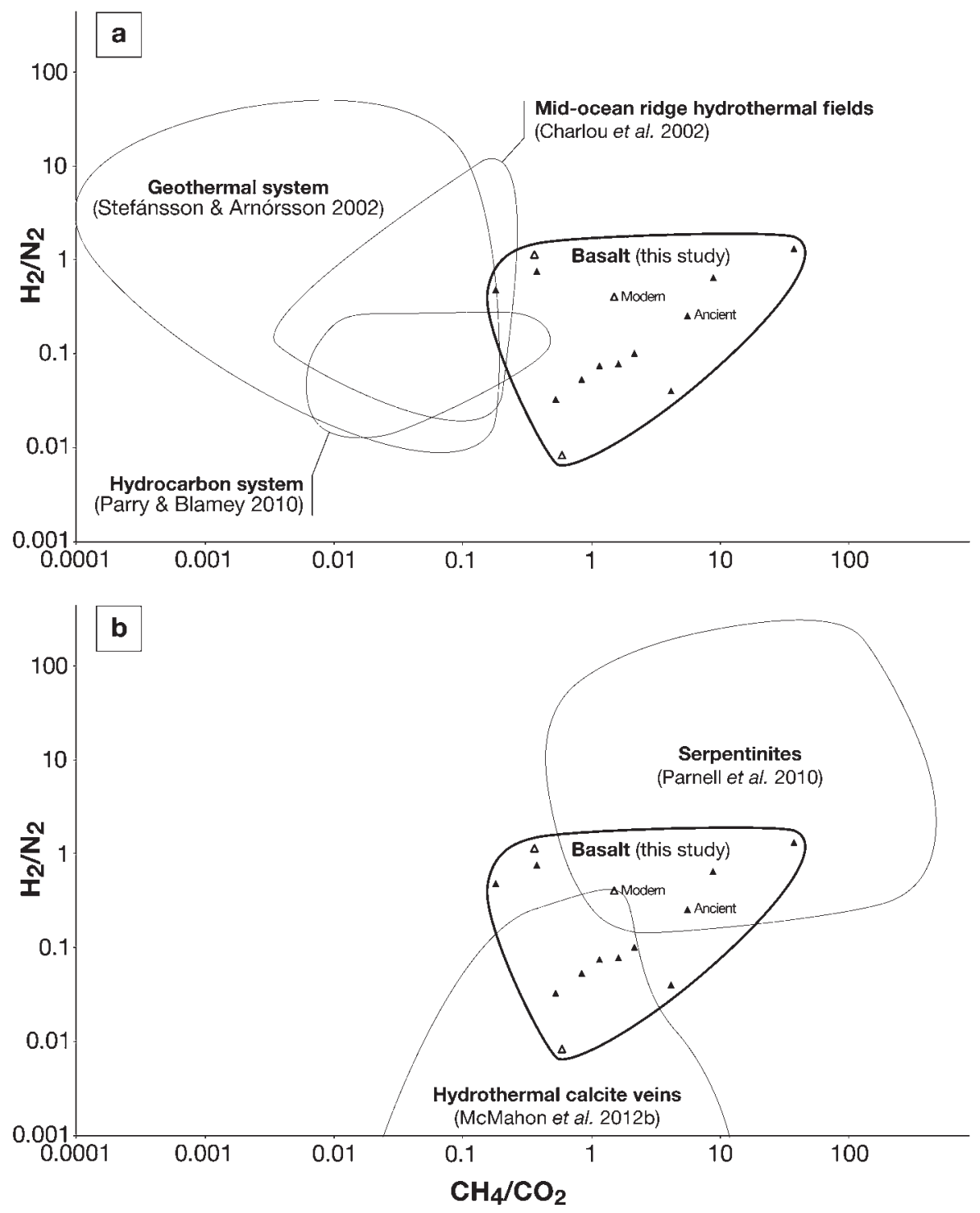

Fig. 6. Comparison of gas compositions in basalts with other $\mathrm{CH}_{4}$-bearing fluids and geological materials. (a) $\mathrm{CH}_{4} / \mathrm{CO}_{2}$ against $\mathrm{H}_{2} / \mathrm{N}_{2}$ molar ratios in evacuated volatiles from unweathered basalts in the present study (filled triangles = ancient basalts; unfilled triangles $=$ Recent basalts) compared with three modern fluids (Parry \& Blamey 2010; Charlou et al. 2002; Stefánsson \& Arnórsson 2002). (b) $\mathrm{CH}_{4} / \mathrm{CO}_{2}$ against $\mathrm{H}_{2} / \mathrm{N}_{2}$ molar ratios in evacuated volatiles from unweathered basalts in the present study (filled triangles = ancient basalts; unfilled triangles $=$ Recent basalts) compared with volatiles evacuated from serpentinites and hydrothermal calcite veins (Parnell et al. 2010; McMahon et al. 2012b).

low $\mathrm{CH}_{4} / \mathrm{CO}_{2}$ ratios at typically basalt quenching temperatures: less than $10^{-6}$ at $1000^{\circ} \mathrm{C}$ (Giggenbach 1997). Where more reducing conditions occur, equilibrium is controlled by graphite and can generate $\mathrm{CH}_{4} / \mathrm{CO}_{2}$ ratios within the range we observed; however, it would be unusual for mid-ocean ridge basalts on Earth to form under these conditions.

In our view, the high $\mathrm{CH}_{4} / \mathrm{CO}_{2}$ ratios in these basalt samples are best explained by hydrothermal fluid- and/or waterrock reactions. Hydrothermal $\mathrm{C}-\mathrm{O}-\mathrm{H}$ fluids in contact with basalt are in redox equilibrium at high $\mathrm{CH}_{4} / \mathrm{CO}_{2}$ well below $500{ }^{\circ} \mathrm{C}$, whether buffered by $\mathrm{QFM}$ or the $\mathrm{FeO}-\mathrm{FeO}_{1.5}$ (quartzfayalite-hematite) 'rock buffer' of Giggenbach (1987). Thus, Giggenbach (1997) describes $\mathrm{CH}_{4}$ production in a 'hydrothermal envelope surrounding the [volcanic] vent system.' Additional $\mathrm{H}_{2}$ and $\mathrm{CH}_{4}$ are likely to have been supplied by the low-temperature aqueous alteration of olivine and pyroxene (serpentinization) in local cumulates, in the underlying ultramafic layers of oceanic crust, and within the basalt itself, even the young Icelandic and Hawaiian basalt. These gases have been generated in the laboratory by the serpentinization of olivine at $30-70{ }^{\circ} \mathrm{C}$ on an experimental timescale (Neubeck et al. 2011).

Both of these mechanisms are likely to have operated on Mars. The surface of Mars is dominated by basalt (McSween et al. 2009), and evidence from orbit (Ehlmann et al. 2010) and meteorites (Changela \& Bridges 2011) shows that the basalt is at least partially altered to serpentinite and other silicates. Olivine and pyroxene cumulates, as preserved in the Chassigny and Nakhla Martian meteorites, respectively, are particularly vulnerable to serpentinization. The Martian mantle is also 


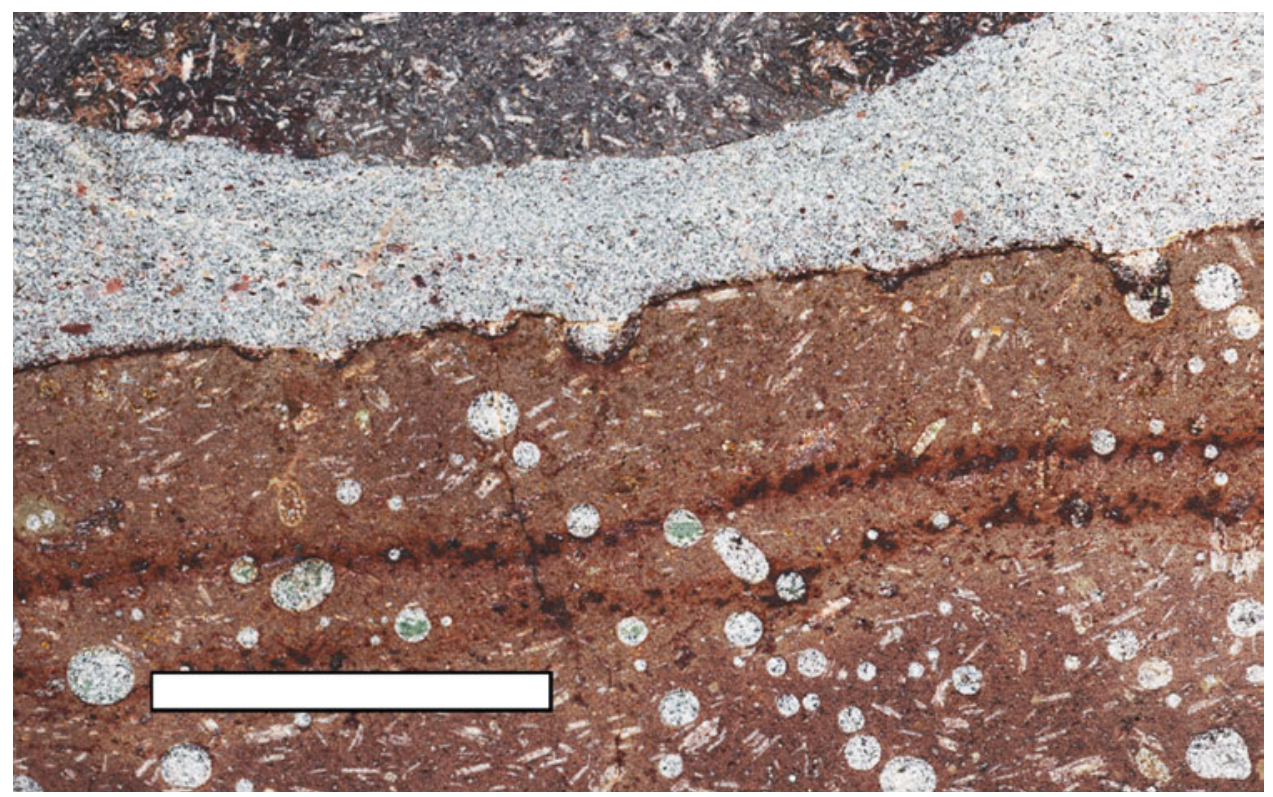

Fig. 7. Photograph of contemporaneously weathered basalt. Weathered basalt (red coloured by the oxidation of iron) in which vesicles have been filled with calcite (white) before erosion of basalt and incorporation into conglomerate, in which fine matrix intrudes into vesicles where calcite has been dissolved. This demonstrates rapid uptake of $\mathrm{CO}_{2}$ (sequestered as calcite) into basalt, where interaction with hydrogen would yield $\mathrm{CH}_{4}$. The scale bar is $5 \mathrm{~cm}$ long.

believed to be more iron-rich than the Earth's, such that the $\mathrm{Fe}-\mathrm{Mg}$ (solid-solution) minerals involved in serpentinization reactions are likely to contain more $\mathrm{FeO}$ and may thus release more $\mathrm{H}_{2}$ and $\mathrm{CH}_{4}$ (Sleep et al. 2004; Bridges \& Warren 2006). Moreover, the Martian mantle is expected to be saturated with graphite and more reduced than QFM (and the Earth), such that hydrothermal fluids at equilibrium will contain a higher proportion of $\mathrm{CH}_{4}$ (Lyons et al. 2005; Hirschmann \& Withers 2008). Steele et al. (2012) have identified reduced organic macromolecular carbon in diverse Martian meteorites, which they interpret as a precipitate from $\mathrm{C}-\mathrm{O}-\mathrm{H}$ fluids.

There are several plausible mechanisms by which volatileescape from altered ancient basalt could contribute to Martian atmospheric $\mathrm{CH}_{4}$ : in the surface, wind abrasion, impact erosion due to micrometeorites and meteorites, freeze-thaw weathering, hot-cold weathering, or salt weathering; and in the subsurface, geochemical activity and hydrothermal fracturing enhanced by geothermal convection (Travis et al. 2003).

The gas data emphasize that basalts are sinks for carbon. This is why they are attracting strong attention for their potential in $\mathrm{CO}_{2}$ sequestration (McGrail et al. 2006; Oelkers et al. 2008; Schaef et al. 2009, 2010). On Mars, there is growing evidence that carbonate formation is widespread (Michalski \& Niles 2010; Niles et al. 2010; Chassefière \& Leblanc 2011) and must be contributing to $\mathrm{CO}_{2}$ drawdown. The occurrence of pre-terrestrial low-temperature carbonates in Martian meteorites (Carr et al. 1985; Changela \& Bridges 2011) shows that basalts contribute to drawdown on Mars, as on Earth. At least some of this carbonate precipitation may have been surficial (Knauth et al. 2003; Halevy et al. 2011), as with carbonates in terrestrial basalts (Fig. 7). $\mathrm{CO}_{2}$ extracted from the atmosphere in this way is available for conversion to $\mathrm{CH}_{4}$ when coupled with serpentinization in basalts. Thus, carbon from both atmosphere and lithosphere could contribute to fuelling a putative methanotrophic biosphere on Mars.

\section{Conclusions}

These results show that $\mathrm{CH}_{4}$ is retained within a range of basalts, including cross-cutting hydrothermal mineral veins, which may be capable of remobilizing ancient $\mathrm{CH}_{4}$ and venting it to the atmosphere. Several other mechanisms may also plausibly release $\mathrm{CH}_{4}$ from Martian basalt. More work is needed to establish whether Martian basalts or meteorites contain quantities of ancient $\mathrm{CH}_{4}$ comparable with their terrestrial counterparts and whether they are a likely source for the spatially and temporally variable $\mathrm{CH}_{4}$ in the atmosphere. Indeed, the CFS technique demonstrated here could be adapted for use on Mars, perhaps by the modification of existing mass spectrometry techniques for Mars (e.g. the Sample Analysis at Mars package flying on NASA's Mars Science Laboratory).

Evidence of serpentinization or hydrothermal alteration on Mars would imply that liquid water, water-rock redox gradients, and gases including $\mathrm{CO}_{2}, \mathrm{H}_{2}$ and $\mathrm{CH}_{4}$ - all potential energy sources for metabolism - have all been present in the subsurface. These conditions are suggestive of a habitable environment. The products of serpentinization are known to support complex ecosystems in the Earth's oceanic crust and have also been implicated in the origin of life (Sleep et al. 2004, 2011; Kelley et al. 2005; Hellevang 2008). Biogenic $\mathrm{CH}_{4}$ on Earth is classically distinguished from abiogenic $\mathrm{CH}_{4}$ by its light carbon isotopic composition (i.e. very negative $\delta^{13} \mathrm{C}$ ), 
although this test for biogenicity can yield false positives where isotopic fractionation is induced by hydrothermal processes (Horita \& Berndt 1999), as well as false negatives in circumstances where biogenic $\mathrm{CH}_{4}$ is isotopically heavy (Takai et al. 2008). Moreover, interpretation of $\delta^{13} \mathrm{C}$ in Martian $\mathrm{CH}_{4}$ will be challenging without a deeper understanding of the Martian carbon cycle than is presently available. Thus, other criteria including geological context, hydrogen isotope composition and degree of co-occurrence with higher hydrocarbons should also be considered in the determination of biogenicity. For this purpose, CFS analysis of $\mathrm{CH}_{4}$ in basalts on Earth and Mars could be coupled with measurements of higher hydrocarbons and carbon- and hydrogen-isotopic analysis.

\section{Acknowledgements}

Dr Paula Lindgren (University of Glasgow), Mr Sam Spinks (University of Aberdeen) and Professor Martin Brasier (University of Oxford) each contributed a basalt sample for analysis. Colin Taylor assisted in the preparation of samples. Sean McMahon's PhD studentship is funded by the STFC. The manuscript was greatly improved by the comments of Norm Sleep and two anonymous reviewers.

\section{References}

Anderson, F.W. \& Dunham, K.C. (1966). The Geology of Northern Skye. Memoirs of the Geological Survey (Geological Survey of Scotland) HMSO, Edinburgh.

Arai, S., Ishimaru, S. \& Mizukami, T. (2012). Hydrocarbon micro-inclusions in olivine in high-P titanoclinohumite-bearing dunites: hydrocarbon activity in a subduction zone and Ti mobility. Geophys. Res. Abstr. 14, EGU2012-EGU4015.

Blamey, N.J.F. (2012). J. Geochem. Explor, 116-117, 17-27.

Blamey, N.J.F., Parnell, J. \& Longerich, H.P. (2012). Understanding detection limits in fluid inclusion analysis using an incremental crush fast scan method for planetary science. In Proc. Lunar and Planetary Science Conf. XLIII, abstract 1035.

Bluck, B.J. (1992). Pinbain block. In Geological Excursions Around Glasgow and Girvan, ed. Lawson, J.D. \& Weedon, D., pp. 319-338. Geological Society, Glasgow.

Bornhorst, T.J. \& Rose, W.I. Self-guided geological field trip to the Keweenaw Peninsula, Michigan. In Institute on Lake Superior Geology Proceedings 40, part 2. ILSG, Houghton.

Bridges, J.C. \& Warren, P.H. (2006). J. Geol. Soc. 163, 229-251.

Browne, M.A.E. \& Woodhall, D.G. (1999). Geology of the Kirkcaldy Sheet a brief explanation of the geological map. Sheet Explanation of the British Geological Survey 1:50000 Sheet 40E Kirkcaldy (Scotland).

Carr, R.H., Grady, M.M., Wright, I.P. \& Pillinger, C.T. (1985). Nature 314, 248-250.

Changela, H.G. \& Bridges, J.C. (2011). Meteorit. Planet. Sci. 45, 18471867.

Charlou, J., Donval, J., Fouquet, Y., Jean-Baptiste, P. \& Holm, N. (2002). Chem. Geol. 191, 345-359.

Chassefière, E. \& Leblanc, F. (2011). Planet. Space Sci. 59, 207-217.

Craig, L.E. (1983). Trans. R. Soc. Edinburgh Earth Sci. 74, 183-191.

Dentener, R. et al. (2001). Atmospheric chemistry and greenhouse gases. In Climate Change 2001: The Scientific Basis. Contribution of Working Group I to the Third Assessment Report of the Intergovernmental Panel on Climate Change, ed. Houghton, J.T. et al., 881 pp. Cambridge University Press, Cambridge, United Kingdom and New York, NY, USA.

Ehlmann, B.L., Mustard, J.F. \& Murchie, S.L. (2010). Geophys. Res. Letts. 37, L06201.
Eyles, V.I. (1952). The composition and origin of the Antrim laterites and bauxites. Memoirs of the Geological Survey (Geological Survey of Northern Ireland). HMSO, Belfast.

Fisk, M.R. \& Giovannoni, S.J. (1999). J. Geophys. Res. 104, 11805-11815. Fonti, S. \& Marzo, G.A. (2010). Astron. Astrophy. 512, A51.

Formisano, V., Atreya, S., Encrenaz, T., Ignatiev, N. \& Giuranna, M. (2004). Science 306, 1758-1761.

Geminale, A., Formisano, V. \& Giuranna, M. (2008). Planet. Space Sci. 56, 1194-1203.

Giggenbach, W.F. (1987). Appl. Geochem. 2, 143-161.

Giggenbach, W.F. (1997). The origin and evolution of fluids in magmatic-hydrothermal systems. In Geochemistry of Hydrothermal Ore Deposits, 3rd edn, ed. Barnes, H.L., 972 pp. John Wiley \& Sons Inc., New York.

Gough, R.V., Tolbert, M.A., McKay, C.P. \& Toon, O.B. (2010). Icarus 207, $165-174$.

Gower, P. (1977). Scottish J. Geol. 13, 125-133.

Grady, M.M., Verchovsky, A.B. \& Wright, I.P. (2004). Int. J. Astrobiol. 3, 117-124.

Halevy, I., Fischer, W.W. \& Eiler, J.M. (2011). Proc. Natl. Acad. Sci. U.S.A. 41, 16895-16899.

Hellevang, H. (2008). Int. J. Astrobiol. 7, 157-167.

Hirschmann, M.M. \& Withers, A.C. (2008). Earth Planet. Sci. Lett. 270, $147-155$.

Horita, J. \& Berndt, M.E. (1999). Science 285, 1055-1057.

Kawai, T. et al. (2007). Precambrian Res. 153, 11-28.

Kelley, D.S. (1996). J. Geophys. Res. 101, 2943-2962.

Kelley, D.S. et al. (2005). Science 307, 1428-1434.

Knauth, L.P., Brilli, M. \& Klonowski, S. (2003). Geochim. Cosmochim. Acta 67, 185-195.

Lefèvre, F. \& Forget, F. (2009). Nature 460, 720-723.

Lowenstern, J.B. (2001). Miner. Deposita 36, 490-502.

Lyle, P. \& Preston, J. (1993). J. Geol. Soc. 150, 109-120.

Lyons, J.R., Manning, C. \& Nimmo, F. (2005). Geophys. Res. Lett. 32 , L131201.

McGrail, B.P., Schaef, H.T., Ho, A.M., Chien, Y-J., Dooley, J.J. \& Davidson, C.L. (2006). J. Geophys. Res. 111, doi:10.1029/ 2005JB004169,2006

McMahon, S., Parnell, J., Burchell, M. \& Blamey, N.J.F. (2012a). Methane retention by rocks following simulated meteorite impacts: implications for mars. In Proc. Lunar and Planetary Science Conf. XLIII, abstract 1040 .

McMahon, S., Parnell, J. \& Blamey, N.J.F. (2012b). Int. J. Astrobiol. 11, 163-167.

McSween, H.Y. Jr., Taylor, G.J. \& Wyatt, M.B. (2009). Science 324, 736-739.

Michalski, J.R. \& Niles, P.B. (2010). Nature Geosci. 3, 751-755.

Moore, J.N., Norman, D.I. \& Kennedy, B.M. (2001). Chem. Geol. 173, 3-30.

Mumma, M.J., Villanueva, G.L., Novak, R.E., Hewagama, T., Bonev, B.P., DiSanti, M.A., Mandell, A.M. \& Smith, M.D. (2009). Science 323, 1041-1045.

Neubeck, A., Duc, N.T., Bastviken, D., Crill, P. \& Holm, N.G. (2011). Geochem. Trans. 12, 6.

Niles, P.B., Boynton, W.V., Hoffman, J.H., Ming, D.W. \& Hamara, D. (2010). Science 329, 1334-1337.

Norman, D.I. \& Blamey, N.J.F. (2001). Quantitative analysis of fluid inclusion volatiles by a two quadrupole mass spectrometer system. In ECROFI (European Current Research on Fluid Inclusions) XVI, pp. 341-344. Elsevier, Amsterdam.

Norman, D.I. \& Moore, J.N. (1997). Gaseous species in fluid inclusions: a fluid tracer and indicator of fluid processes. In ECROFI (European Current Research on Fluid Inclusions) XIV, pp. 243-244. CNRS-CREGU, Vandoeuvre-lès-Nancy.

Oelkers, E.H., Gislason, S.R. \& Matter, J. (2008). Elements 4, 333-337.

Ogenhall, E. (2007). Geol. Forenics Forh. 129, 211-226.

Oze, C. \& Sharma, M. (2005). Geophys. Res. Lett. 32, L10203.

Parnell, J., Boyce, A.J. \& Blamey, N.J.F. (2010). Int. J. Astrobiol. 9, 193-200. 
Parry, W.T. \& Blamey, N.J.F. (2010). Chem. Geol. 278, 105-119.

Polat, A., Kerrich, R. \& Wyman, D. (1998). Tectonophysics 289, 295-326.

Sachan, H.K., Mukherjee, B.K. \& Bodnar, R.J. (2007). Earth Planet. Sci. Lett. 257, 47-59.

Schaef, H.T., McGrail, B.P. \& Owen, A.T. (2009). Energy Procedia 1, 4899 4906.

Schaef, H.T., McGrail, B.P. \& Owen, A.T. (2010). Int. J. Greenhouse Gas Control 4, 249-261.

Schulte, W., Widani, C., Hofmann, P., Bönke, T., Re, E. \& Baglioni, P. (2008). Design and breadboarding of the sample preparation and distribution system of the ExoMars mission. In Proc. Ninth International Symposium on Artificial Intelligence, Robotics and Automation in Space. ESA.

Sleep, N., Meibom, A., Fridriksson, Th., Coleman, R.G. \& Bird, D.K. (2004). Proc. Nat. Acad. Sci. U.S.A. 101, 12818-12823.

Sleep, N., Bird, D.K. \& Pope, E. (2012). Annu. Rev. Earth Planet. Sci. 40, 277-300.
Sleep, N.H., Bird, D.K. \& Pope, E.C. (2011). Phil. Trans. Royal Soc. B: Biol. Sci. 366, 2857-2869.

Steele, A. et al. (2012). Science 337, 212-215.

Stefánsson, A. \& Arnórsson, S. (2002). Chem. Geol. 190, 251-271.

Takai, K., Nakamura, K., Toki, T., Tsunogai, U., Miyazaki, M., Miyazaki, J., Hirayama, H., Nakagawa, S., Nunoura, T. \& Horikoshi, K. (2008). Proc. Natl. Acad. Sci. U.S.A. 105, 1094910954.

Thomas, C.W. (1999). Garron point to slug head. In Caledonian Igneous Rocks of Great Britain, ed. Stephenson, D., Bevins, R.E., Millward, D., Highton, A.J., Parsons, I., Stone, P. \& Wadsworth, W.J., 648 pp. Geological Conservation Review Series, No. 17, Joint Nature Conservation Committee, Peterborough.

Travis, B.J., Rosenberg, N.D. \& Cuzzi, J.N. (2003). J. Geophys. Res 108, 8040-8054.

Welhan, J.A. (1988). Can. J. Earth Sci. 25, 38-48.

Zahnle, K., Freedman, R.S. \& Catling, D.C. (2011). Icarus 212, 493-503. 